\title{
Approaches of the Science Course of the Childrens' Whose Mothers' Participated the Family Education Program: Case Study
}

\author{
Anıl Görkem ${ }^{1 *}$ \\ ${ }^{1}$ European University of Lefke, Lefke, N. CYPRUS
}

Received 19 September 2017 • Revised 10 October 2017 • Accepted 15 October 2017

\begin{abstract}
This study investigates the concern of science course whose mothers' completed parenting education programme 3 years ago. The parenting education programme was about families who had children 7-11 years old. The investigation was done with 4 mothers. This case study were examined with 3 semi-structured questions. The analysis of data is done with content analysis. The questions focused on to learn concern of science courses behind to childrens' attitues to the homeworks, succeses at science courses and the activities with their families. The age range of mothers were between 35-40 and two of children 9, 3 children 10 and 1 of the child was 14 years old. As a result, success of students; considering to vulnerabilities for completeing homeworks and the activities that they did with their families was high. The school performances of children showed that, five of them were succesful in science cources. In addition, five of six students are vulnerable to complete their homeworks and also prefer to do simple experiments implemented in to playing and games with their parents. This study revealed that, the children which their families attended to parenting education programme were succesful and interested in science courses, which contributes to their cognitive improvement.
\end{abstract}

Keywords: science education, parenting education programme, mothers of $7-11$ years old childrens', case study

\section{INTRODUCTION}

Science education is the education of interesting and surprising things around a child including the food he/she eats, the water he/she drinks, the air he/she breaths, and the electricity used. In this context, science education should be given by appropriate methodology and techniques taking into account children's interests, requirements, needs, and level of developments as well as environmental opportunities (Gürdal, 1988).

Science education helps children to develop creative thinking, and hence understand and love his/her environment. Furthermore, it assists pupils in having more effective communication with their families, friends, and teachers, developing language skills, and acquiring logical thinking skills (Hançer et al, 2003). Logical thinking is one of the important areas of work for Educational Psychology, Developmental Psychology, and Science Education. Research has shown the key role of the ability of logical thinking in not only success in mathematics and science but also in general achievement (Tobin and Capie 1982, Lawson, 1982, Williams and Cavallo, 1995; Atay, 2006, Lawson, Banks and Logvin, 2006). Many researchers emphasise the positive role of family education in a child's success, and the importance of parents in his/her cognitive, social, emotional, motor, and personality development (Yavuzer, 1995; Kağıtçıbaşı 1989; quoted byErkan, 2010; Poyraz and Özyürek, 2005; Dubow andHuesman 1987; quoted by Şimşek, 2007).

Frederick (1995, b.67) defines the concept of family as the first unit that reflects culture and where a child's socialisation starts depends on sociological based. Kaya and Siyez (2014), stating that family is the first environment which the child finds herself/himself and also develops her/his personality based on psychological view.

Rapidly changing socio-economic structures have brought the transformation of the family from the traditional family structure to the core family structure. In traditional family structures, since parents, child(ren) and 


\section{Contribution of this paper to the literature}

- The case study was carried out with six children of 9 to 15 years of ages, and four mothers. All adult participants were in employment. Their economic status was described as well generally. All of the children concerned had been through pre-school education. All of the participating mothers attended to a three and half months long family education programme for 7-11 years old children, led by the author of this work three years ago.

- The findings of this work show that the children of the mothers who participated in the family education programme had academic success in science education.

- Reflecting on the findings of this work, it is possible to say that the children of the mothers who participated in family education enjoyed homework and other studies in science. Alongside having mothers who knows how to approach children regarding their homework, family plays an important role in reasoning their behaviours and bringing up children sensitive to their environments.

grandparents lived together, mother always received help from family members, especially in childcare. The core family structure is the smallest unit of the society where parents and children live together. Just like any change, this change necessitates that the need for family education shows itself without dispute. (Varol, 2005) states that as the parents ensure healthy development of their children, through family education they contribute the children more and enable them in thinking more systematically in the development of their aims.

Yang et al. (2017), reported that, some distinct psychological and behavioral elements of high school students concern their emotional and cognitive responses through science. Considering that family education programmes positively impact many developmental areas, it becomes more important to investigate the effect of such programmes on children's analytical thinking (cognitive development) specifically. This is evident from the fact that research work points at a positive correlation between logical thinking and success (Johnson and Lawson, 1998). Success in science education indicates a relationship to the ability of logical thinking (Tobin and Capie, 1981).

Work done clearly shows the importance of the competence of parents in enabling them be effective in their children'sdevelopment. Parenting is not limited to providing biological necessities but ability to help children develop skills for sustainable lives. This is only achievable through the competencies of parents. Receiving education on a subject supports competences at the same time (Sayllır, 2015).

As stated above, it is believed that the importance of science education in the development of logical thinking may play an important role in assessing in measuring the logical thinking of the children of families who received family education. Studies of research work carried out in Turkey and North Cyprus as well as internationally show no such work. This sort of research may lead to more detailed work in the field. Therefore, the case study presented in this work is important in the sense that it may shed a light on work in this important area.. Children's academic development will provide us with insightful knowledge at the points where we can observe their cognitive development.

\section{METHODOLOGY}

\section{Research Pattern}

In this work, a case study is used as a qualitative research approach. One of the most fundamental characteristics of qualitative research method is that an event or a phenomenon is investigated from the viewpoint(s) of a subject/subjects (Ekiz, 2009). Qualitative method also emphasises the importance of the context that helps to understand and make sense of the phenomenon studied. (Happner ve ark., 2008). The investigation of a case/situation enables in depth investigation of a phenomenon. (Merriam, 1998).

\section{Environment and Participants}

The participating mothers were asked to state the following in relation to themselves: age, occupation, level of education, and marital status. The level of income of the family (good, average, poor; as they interpret), father's occupation were other questions asked on demographics. The chosen participant's previous attendance to family education programmes is important. The participants of the study are four out of fifteen mothers who attended a family education programme in 2014, which is in line with the education the program executor received. The programme was for the parents of the 7-11 age group, part of The Family Education Programme for 0-18 age group, developed for parents by the Ministry of Education of the Republic of Turkey, General Directorate of Apprenticeship and Non-formal Education, 
Table 1. The demographics of the participating mothers

\begin{tabular}{|c|c|c|c|c|c|c|c|}
\hline Mother & Age & $\begin{array}{l}\text { No of } \\
\text { children }\end{array}$ & Occupation & Education & Marital status & $\begin{array}{c}\text { Partners } \\
\text { occupation }\end{array}$ & $\begin{array}{c}\text { Children's attendance to pre- } \\
\text { school education }\end{array}$ \\
\hline Mother 1 & 40 & 2 & Secretary & $\begin{array}{l}\text { Bachelor } \\
\text { degree }\end{array}$ & Married & CivilServant & Attended pre-school education \\
\hline Mother 2 & 37 & 1 & Civil Servant & High school & Married & CivilServant & Attended pre-school education \\
\hline Mother 3 & 35 & 1 & Academic & $\begin{array}{l}\text { Bachelor } \\
\text { degree }\end{array}$ & Divorced & CivilServant & Attended pre-school education \\
\hline Mother 4 & 40 & 2 & Secretary & $\begin{array}{l}\text { Bachelor } \\
\text { degree }\end{array}$ & Married & Technician & Attended pre-school education \\
\hline
\end{tabular}

The semi-structured questions prepared for this study were shown to the mothers who participated in the programme in advance. Pre-meetings with mothers were arranged, they were informed about the work, their permissions were taken verbally, and finally they were interviewed at their homes for approximately 3045 minutes. The questions included personal and family information such as the participant's age, level of education, employment, marital status, partner's employment, and children's attendance to pre-school education. The participating mothers were given a representative number for anonymity. This information is given in Table 1.

As shown in Table 1, Mother 1 is 40 years old with twin daughters (10 years old), married, and possesses a university degree. She works as a personal assistant. She has been in a marriage for about 15 years. Her husband has a high school diploma and works as a Civil Servant. She sees their economic status as good. Mother 2 is 37 years old, married for 12 years, and working as a Civil Servant. She possesses a high school diploma, and has a nine years old son. She sees their economic status as good. Her husband is a university graduate working as a Civil Servant. Mother 3 is 35 years old and has a 9 year old daughter. She had a divorce two years ago, now living with her daughter and working at a state university as an academic. She sees her economic status as good. Mother 4 has a 10 years old daughter and a 14 years old son. She works as a personal assistant, while her husband is employed as a technician in the private sector. She sees their economic status as average.

It is stated by their mothers that all children participating in this study have attended pre-school education.

\section{Collecting Data}

In this study the data were collected by a semi-structured interview technique. The semi-structured interview questions were prepared in accordance with the guidance given in the relevant literature and the questions were collected under three categories. Under the first category that related to identifying the success of the children in science education, questions were chosen to reflect the success at school as measured by academic assessment. To look into the children's attitudes towards homework, in the second category, questions were prepared considering that children work voluntarily on what they love and have an interest in. The third category contains questions on understanding the role of parents in being a role model and directing the children in playing games. Each category contains 3-6 questions. When needed, new questions were asked to mothers to have more explanation.

Interview questions:

a. Category one: Success in science education

1. What grade did your child obtain in his/her end of year report?

2. Is your child successful in science education? Why?

3. In your opinion, what subjects attract your child's interest more than others? Why?

4. Are the topics in your child's science education difficult? How is his/her level of understanding?

b. Category two: The child's attitude towards the science homework asnd interst in the subject

1. How long are the science study periods and breaks of your child?

2. Does your child get bored when studying science?

3. Does your child get bored when working on science homework?

4. Does your child want to try at home what he/she learns in science classes?

5. Does your child want to repeat at home what he/she learns in science classes?

6. Does your child research what he/she learnt in science class using books or searching the Internet? 
Table 2. General evaluation of mothers according to categories

\begin{tabular}{ccccc}
\hline Mother & Children & $\begin{array}{c}\text { Category one: } \\
\text { Success in science }\end{array}$ & $\begin{array}{c}\text { Category two: Approach to science } \\
\text { homework and interest in science }\end{array}$ & $\begin{array}{c}\text { Category three: Game } \\
\text { activities with parents }\end{array}$ \\
\hline \multirow{2}{*}{ Mother 1} & First twin daughter & Successful & Successful & Successful \\
& Second twin daughter & Successful & Successful & Successful \\
\hline Mother 2 & Son & Successful & Unsuccessful & Successful \\
\hline Mother 3 & Daughter & Successful & Successful & Successful \\
\hline \multirow{2}{*}{ Mother 4 } & Elder son & Successful & Successful & Successful \\
\hline
\end{tabular}

\section{c. Category three: Game activities with parents}

1. What are the factors determining your childliking/disliking science lessons?

2. Do you pay attention to choose games appropriate to science education when playing with your child?

3. Is the game environment you offer to your child an appropriate environment to experiment with what he/she learnt in science classes? How is it?

\section{Data Analysis}

In the analysis of the data collected, content analysis have been used. As Yıldırım and Şimşek (2006) express, content analysis is organising and interpreting data brought together with specific concepts and themes in a way that readers can understand. These arrangements and encodings are a systematic technique, based on specific rules, in which the texts expressed on the call are summarized with smaller content categories (Büyüköztürk, Çakmak, Akgün, Karadeniz and Demirel, 2009).

All interviews have been recorded (with mothers verbal permission), the questions were considered and a deductive method was followed. The questions shown were presented in the order shown here and answers expected. Then the factors of each category were identified. In the analysis, rather than the actual names of the participants, Mother 1-2-3-4 is used.

\section{Findings}

In this section, the mothers' answers to questions are evaluated under three main categories. The findings are presented in Table 2.

As it can be seen in Table 2;

\section{a. Category one: Success in science education}

In response to a question regarding their children's success in science education, the mothers who participated in family education stated that all the children have been successful in science with grade A in their end of year reports.

Mother 1: ... Although they are twin, I observed that they get different grades in many subjects. However, in science, they are both very successful. I can see that they have more interest in science then other subjects. When they study science at school, they are very keen in carrying out experiments on the topic....

Mother 2:... In his end of year report, my son is successful in all subjects but more successful in music. Because he prefers to watch music channels on TV and show interest in musical instruments.

Mother 3: ... I can tell from the end of year report that he is successful, but also he loves always mixing things, inventing something new, and discovering things. Besides investigations, he is very sensitive towards the nature and cleaning the environment he is in. His questions on the space and things he wants to know about materials never end. He is also successful in mathematics and other subjects, but in those subjects he completes his homework and stops....

Mother 4: My boy loves science subjects more than my daughter. However, they are both very successful as their grades show. Both always score A in this topic... They are both successful in grasping concepts. I can say that they find it more difficult in grasping concepts in Turkish grammar. They have a special interest in this subject... 


\title{
b. Category two: Child's behaviour towards science homework and her/his interest in the subject
}

Apart from two mothers, the mothers of the remaining five children stated that their children are more interested in studying science subjects and doing coursework compared to other subjects.

Mother 1:... If they have homework in science or an exam, they both study until the task is finished. For other subjects, I have to constantly remind them to work on the task given...

Mother 2: ... In fact my son always gets bored when he works on his homework. For any subject, we find it difficult to make him sit down and work. He is never bored of playing games or listening to music...

Mother 3: ... In fact she is very excited in every project or homework she brings home but more excited in projects. She collects all the material needed and works meticulously. But especially in doing homework in nice writing skills she tells us that she gets bored. She does not study hard. But I guess since she listens to the teacher carefully in class environment, she grasps topics very well...

Mother 4: My daughter is younger but compared to his brother, she is more tense and discreet. Her elder brother completes his science projects with care and diligently. But my daughter often watches videos on the Internet and tries the mixtures she sees there, and experiments with what she sees there...

\section{c. Category three: Game activities with parents}

Again in this category, all mothers but mother number 2 stated that at home one or both parents have activities with their children involving trial and error, and cause and consequence.

\begin{abstract}
Mother 1: ... I think it's our influence that they like games involving mixing things. Since we have a garden at home, whenever weather permits, we encourage the girls to play in the garden. In the beginning, when they were younger, we, both parents used to go downstairs and play mixing soil and water, and investigate the insects in the soil etc....
\end{abstract}

Mother 2: ... When choosing a game, I pay attention to choosing something so that my son can play without getting sick or dirty. We play mind games but he gets bored quickly in that case. If he plays with water he quickly gets wet; to be honest, I don't want him to dothat because he may get sick...

Mother 3: ... In fact considering my daughter's games, I always paid attention to buying ageappropriate toys from her birth onwards. I have always been selective that toys chosen are educational, developmental and lend themselves to individual as well as group play. Yes we have a play environment at home. Her room is hers and she is free there. Again, we buy age appropriate chemistry sets and conduct experiments together. In general she makes toy choices and she chooses these kinds of toys herself. ...

Mother 4: In fact they work more with their dad in such activities. Since their dad adds fun to such activities they love these activities. Regarding toys, yes, we pay attention to choose toys appropriate to science education, but my daughter wants to follow what her elder brother does and hence she is involved with activities a bit ahead of her age. ...

\section{CONCLUSION, DISCUSSIONS, AND RECOMMENDATIONS}

Research work presented here reports findings on the approach of children to science education whose mothers attended a family education programme three years ago. The findings show that children of such mothers have a positive approach to science education. The programme offered contained information on the developmental periods of children specifically. Amongst these developmental areas, physical, social, and cognitive development can be stated. It is believed that parents' competencies especially on cognitive development can determine their approaches to science education (Valanides, 1997; Lawson, 1982). As literature review revealed that science and mathematics education are predominantly emphasised in measuring logical thinking had a positive impact on the decision on concentrating on science education for this work.

The mothers who participated in research are of 35-40 years old and one mother was a divorcee. The case study was carried out with six children of 9 to 15 years of ages, and four mothers. All adult participants were in employment. Their economic status was described as well generally. All of the children concerned had been through pre-school education. All of the participating mothers attended to a three and half months long family education programme for 7-11 years old children, led by the author of this work three years ago. Şahin et al.(2010) revealed that, the parents'level of the knowladge of science and their childrens' success at science course had 
significante positive relationship. Beside of this, Ersoy and Anagün (2009) found that, teachers had difficulty about homeworks because of the internet, students and parents.

The findings of this work show that the children of the mothers who participated in the family education programme had academic success in science education. There are research works on the success of the children of mothers who attended family education programmes, in science. However, only in (Sayllır, 2015), findings show that the mothers who participated in a family education program she organised are competent in their children's academic development. Competences of parents in this area would determine their approaches to their children and this would inarguably lead to bringing up successful children.

Reflecting on the findings of this work, it is possible to say that the children of the mothers who participated in family education enjoyed homework and other studies in science. Alongside having mothers who knows how to approach children regarding their homework, family plays an important role in reasoning their behaviours and bringing up children sensitive to their environments. It can be stated that especiallythe sensitivity in the family education program has been successfully reflected in dealing with their children. The use of creativity by the children enthusiastically executing projects shows how their creativities have been developed. All children subjects of this study participated in pre-school education as stated above. It worth noting that, the grades of children who have been through pre-school education are significantly higher than those who have not (Yaşar ve Aral, 2010).

Especially in primary education, the importance of games in children's development is of paramount importance. Research findings show that mothers participating in family education play science games with their children and/or provide them with such opportunities. In their work, Trnova and Trna (2015) have reached the conclusion that in the science education of pre-school children, applied and games oriented approaches are important. Beside of this, Xie and Gan (2017), relieved that, parents whose going out with children for walking or playing with their children influence positively childrens emotional and social development. According to the results of experimental studies which performed by Bayazıtoğlu (1996), Ercanlı (1997) and Tural (2005); the lessons such as maths and sciences learned more effective with games.

In line with these finding, the following recommendations can be made for further work:

1. Comparisons can be made through families attending and not attending family education programmes,

2. Using measures assessing logical thinking, research can be carried out on children as well to support findings,

3. As educational techniques are discussed on the logical development of children (Hançer et al., 2003), besides educational techniques, the education of families on the development of children will further support cognitive development of their children, Education is meaningful in its entirety. The education of families, quality education at school, and the provision of necessary educational materials will strengthen education. Hence, it recommended that parent education programmes are offered more widely in all developmental areas.

\section{REFERENCES}

Atay, P. D. (2006). Relative Influence of Cognitive and Motivational Variables on Genetic Concepts in Traditional and Learning Cycle Classrooms (Unpublished Doctoral Thesis). Ankara: Orta Doğu Teknik Üniversitesi/Fen Bilimleri Enstitüsü.

Bayazıtoğlu, E. N. (1996). İlköğretim 2. Sınıf Hayat Bilgisi Dersinde Ĕ̆itsel Oyunlar, Erişi ve Kalıcılık (Unpublished Doctoral Thesis). Hacettepe Üniversitesi Sosyal Bilimler Enstitüsü.

Büyüköztürk, Ş.., Çakmak, E. K., Akgün, Ö. E., Karadeniz, Ş., \& Demirel, F. (2009). Bilimsel araştırma yöntemleri (5. bs.). Ankara: PegemA Yayıncılık.

Ekiz, D. (2009). Bilimsel Araştırma Yöntemleri. Ankara: Anı Yayıncılık.

Ercanlı, D. (1997). İlköğretim Okullarını 4. Sinıflarında Dünyamız ve Gökyüzü Ünitesinin Öğretilmesinde Oyun ve Modellerin Etkisi (Unpublished Masters Thesis). Marmara Üniversitesi Eğitim Bilimleri Enstitüsü.

Erkan, S. (2010). Aile ve aile eğitimi ile ilgili temel kavramlar. Temel Z. F. (ed.), aile eğitimi ve erken çocukluk eğitiminde aile katılım çalışmaları. Ankara: Anı Yayıncılık, 3-43.

Ersoy, A., \& Anagün, Ş. S. (2009). Sınıf öğretmenlerinin fen ve teknoloji dersi ödev sürecine ilişkin görüşleri. Necatibey Ĕ̆itim Fakültesi Elektronik Fen ve Matematik Eğitimi Dergisi, 3(1).

Frederick D. (1995). Narrative of the life of Frederick Douglass, an American slave. US: Globe Fearon.

Gürdal, A (1988). Fen Öğretimi. Deniz Kuvvetleri Komutanlı̆̆ı Yayınlan, 21, 34-49.

Hançer, A. H., Şensoy, Ö., \& Yıldırım. H. İ. (2003). İlköğretimde çağdaş fen bilgisi Öğretiminin önemi ve Nasıl olması gerektiği üzerine bir değerlendirme. Pamukkale Üniversitesi, Eğitim Fakültesi Dergisi, 13(1). 
Heppner, P. P., Wampold, B. E., Jr. Kivlighan, D. M. (2008). Psikolojik Danışmada Araştırma Yöntemleri. (D.M. Siyez, Çev. Ed.). Ankara: Mentis Yayıncılık.

Johnson, M. A., \& Lawson, A. E. (1998). What Are The Relative Effects of Reasoning Ability and Prior Knowledge on Biology Achievement in Expository and Inquiry Classes? Journal of Research in Science Teaching, 35(1), 89103.

Kaya, A., \& Siyez, D. (2014). Aile eğitimi kurs programı (0-18 yaş aile eğitim programı). Ankara: Milli Eğitim Bakanlı̆̆ı.

Lawson, A. E. (1982). Formal Reasoning, Achievement, and Intelligence: An Issue of Importance. Science Education, 66(1), 77-83.

Lawson, A. E., Banks, D. L., \& Logvin, M. (2006). Self-Efficacy, Reasoning Ability, and Achievement in College Biology. Journal of Research in Science Teaching. doi:10.1002/tea.20172

Merriam, S. (1998). Qualitative research and case study applications in education. San Francisco, CA: Jossey-Bass.

Poyraz, H.. \& Özyürek, A. (2005).Okul Öncesi 5-6 Yaş Çocukların Problem Davranışları ve Ebeveynlerin Disiplin Yöntemlerinin İncelenmesi, Milli Eğitim Dergisi, (166), 83-97. Retrieved from http://dhgm.meb.gov.tr/yayimlar/dergiler/Milli_Egitim_Dergisi/166/index3ozyurek..htm

Sayılır, A. (2015). 7-11 Yaş Aile Ĕ̆itim Programının Annelerin Ebeveynlik Yetkinliği Düzeylerine Etkisi (Doctoral Thesis). TRNC: Uluslararası Kıbrıs Üniversitesi/Lisansüstü Eğitim-Öğretim ve Araştırma Enstitüsü.

Sen, A. Z., \& Nakiboglu, C. (2012). Analyze of high school chemistry textbooks in terms of science process skills. Journal of Kırşehir Education Faculty (KEFAD), 13(3), 47-65.

Şahin, R., Sanalan, V. A., Bektaş, Ö., \& Kaygısız, Y. (2010). Ebeveynlerin Fen Okuryazarlık Düzeylerinin İlköğretim 7. Sınıf Öğrencilerinin Fen ve Teknoloji Dersi Başarılarına Etkisi. Erzincan University Journal of Science and Technology, 3(1), 125-143.

Şimşek, B. (2007). Erken çocukluk döneminde uygulanan anne destek programınınannelerin çocuk yetiştirme tutumlar üzerindeki etkilerinin incelenmesi (Masters Thesis). İzmir: Dokuz Eylül Üniversitesi Eğitim Bilimleri Enstitüsü.

Tobin, K. G., \& Capie, W. (1982). Relationships Between Formal Reasoning Ability, Locus of Control, Academic Engagement and Integrated Process Skill Achievement. Journal of Research in Science Teaching, 19(2), 113-121.

Trnova, E., \& Trna, J. (2015). Formation of Science Concepts in Pre-school Science Education. Procedia-Social and Behavioral Sciences, 197, 2339-2346.

Tural, H. (2005). Illköğretim matematik öğretiminde oyun ve etkinliklerle öğretimin erişi ve tutuma etkisi (Unpublished Masters Thesis). İzmir: Dokuz Eylül Üniversitesi.

Valanides, N. C. (1997). Formal Reasoning Abilities and School Achievement. Studies in Educational Evaluation, 23(2), 113-121.

Varol, N (2005). Aile eğitimi. Ankara: Kök Yayıncılık.

Williams, K. A., \& Cavallo, A. M. L. (1995). Reasoning Ability, Meaningful Learning, and Students' Understanding of Physics Concepts. Journal of College Science Teaching, 24(5), 311-314.

Xie, J., \& Gan, Y. (2017). Family Environment Impact on School Readiness of Children in China-Based on the Survey of Wuchuan Autonomous County, Guizhou. Eurasia Journal of Mathematics, Science and Technology Education, 13(10), 6509-6518.

Yang, G., Badri, M., Al-Mazroui, K., Al-Rashedi, A., \& Nai, P. (2017). Science as Interests but not for Career: Understanding High School Students' Engagement in Science in Abu Dhabi. Eurasia Journal of Mathematics, Science E Technology Education, 13(7), 3621-3639.

Yaşar, M. C., \& Aral, N. (2010). Yaratıcı Düşünme Becerilerinde Okul Öncesi Eğitimin Etkisi. Kuramsal Eğitimbilim, 3(2), 201-209.

Yavuzer, H. (1995). Çocuk ve suç. İstanbul: Remzi Kitapevi.

Yıldırım, A., \& Şimşek, H. (2006). Sosyal bilimlerde nitel araştırma yöntemleri (5. bs.). Ankara: Seçkin Yayıncılık.

\section{http://www.ejmste.com}

